\title{
Brief Research Communication Association of the Dopamine Receptor D4 (DRD4) Gene 7-Repeat Allele With Children With Attention-Deficit/Hyperactivity Disorder (ADHD): An Update
}

\author{
M.C. Gornick, ${ }^{1}$ Anjene Addington, ${ }^{1 *}$ P. Shaw, ${ }^{1}$ A.J. Bobb, ${ }^{1}$ W. Sharp, ${ }^{1}$ D. Greenstein, ${ }^{1}$ \\ S. Arepalli, ${ }^{2}$ F.X. Castellanos, ${ }^{3}$ and J.L. Rapoport ${ }^{1}$ \\ ${ }^{1}$ Child Psychiatry Branch, NIMH, NIH, Bethesda, Maryland \\ ${ }^{2}$ Laboratory of Neurogenetics, NIA, NIH, Bethesda, Maryland \\ ${ }^{3}$ New York University Child Study Center, New York, New York
}

Polymorphisms of the dopamine receptor D4 gene DRD4, 11p15.5, have previously been associated with attention-deficit/hyperactivity disorder (ADHD) [Bobb et al., 2005; Am J Med Genet B Neuropsychiatr Genet 132:109-125; Faraone et al., 2005; Biol Psychiatry 57:1313-1323; Thapar et al., 2005; Hum Mol Genet 14 Spec No. 2:R275R282]. As a follow up to a pilot study [see Castellanos et al., 1998; Mol Psychiatry 3:431434] consisting of 41 probands and 56 controls which found no significant association between the DRD4 7-repeat allele in exon 3 and ADHD, a greatly expanded study sample (cases $n=166$ and controls $n=282)$ and long term follow-up $(n=107$, baseline mean age $n=9$, follow-up mean age of $n=15)$ prompted reexamination of this gene. The DRD4 7-repeat allele was significantly more frequent in ADHD cases than controls $(O R=1.2$; $P=0.028$ ). Further, within the ADHD group, the 7-repeat allele was associated with better cognitive performance (measured by the WISC-III) $(P=0.013-0.07)$ as well as a trend for association with better long-term outcome. This provides further evidence of the role of the DRD4 7-repeat allele in the etiology of ADHD and suggests that this allele may be associated with a more benign form of the disorder. (c) 2006 Wiley-Liss, Inc.

KEY WORDS: genetic association; transmission disequilibrium test; quantitative TDT

Please cite this article as follows: Gornick MC, Addington A, Shaw P, Bobb AJ, Sharp W, Greenstein D, Arepalli S, Castellanos FX, Rapoport JL. 2007. Association of the Dopamine Receptor D4 (DRD4) Gene 7-Repeat Allele With Children With Attention-Deficit/Hyperactivity Disorder (ADHD): An Update. Am J Med Genet Part B 144B:379-382.

\footnotetext{
*Correspondence to: Anjene Addington, Child Psychiatry Branch, National Institute of Mental Health, NIH, 10 Center Drive, Bldg. 10, Room 3N-202, Bethesda, MD 20892-1600. E-mail: AddingtA@mail.nih.gov

Received 22 May 2006; Accepted 22 September 2006

DOI 10.1002/ajmg.b.30460
}

\section{INTRODUCTION}

Attention-deficit/hyperactivity disorder (ADHD) is a common, highly heritable childhood disorder defined by chronic inattention, hyperactivity, and impulsivity based on criteria specified in the Diagnostic and Statistical Manual of Mental Disorders, Fourth Edition (DSM-IV) [American Psychiatric Association, 1994]. Family, twin and adoption studies, as well as linkage and association studies, have shown strong genetic contributions to the etiology of ADHD [Faraone and Biederman, 1998; Fisher et al., 2002; Ogdie et al., 2003; ArcosBurgos et al., 2004]. The most consistently replicated candidate gene in $\mathrm{ADHD}$ genetics is the association with the dopamine receptor D4 gene (DRD4) [LaHoste et al., 1996; Smalley et al., 1998; Swanson et al., 1998; Comings et al., 1999; Faraone et al., 1999; Holmes et al., 2000; Muglia et al., 2000; Tahir et al., 2000; Curran et al., 2001; Mill et al., 2001; Roman et al., 2001; Bhaduri et al., 2006]. The majority of these studies have reported on a variable number tandem repeat (VNTR) polymorphism in exon 3 of the $D R D 4$ gene. Despite a few inconsistencies in reported associations of this VNTR and ADHD [Eisenberg et al., 2000; Hawi et al., 2000; Sunohara et al., 2000; Marino et al., 2003; Purper-Ouakil et al., 2005] the majority of reports and several meta-analyses have found positive support for the association [LaHoste et al., 1996; Smalley et al., 1998; Comings et al., 1999; Curran et al., 2001; Mill et al., 2001; Roman et al., 2001; Holmes et al., 2002; Bobb et al., 2005; Faraone et al., 2005; Bhaduri et al., 2006].

In the present study, we used both case-control and familybased designs to test the association between ADHD and the DRD4 7-repeat allele using an expanded sample from a previous pilot study [Castellanos et al., 1998] of ADHD patients recruited as part of a day treatment program at the NIMH.

\section{MATERIALS AND METHODS}

\section{ADHD Subjects}

Children and adolescents $(n=166)$ meeting criteria for Diagnostic Statistical Manual of Mental Disorders, Fourth Edition (DSM-IV) [American Psychiatric Association, 1994] ADHD were recruited locally for this study. Exclusion criteria included a full-scale WISC-III IQ less than 80, significant medical or neurological disorders, or other primary axis I psychiatric disorder. Comorbidity for learning disability, oppositional defiant disorder, and anxiety were permitted. Patients meeting DSM-IV diagnosis of ADHD were administered a Diagnostic Interview for Children and Adolescents (DICA)-Child, Adolescent and Parent versions [Reich, 2000]. Other measures included the Conners Parent and Teacher Rating Scales [Goyette et al., 1978; Werry et al., 1975], Child 
Behavior Checklist [Achenbach and Edelbrock, 1981], Teacher Report Form [Achenbach et al., 1991], Full Scale Wechsler Intelligence Scale for Children, Third Edition (WISC-III), a computerized response inhibition task [Casey et al., 1993], and an anatomic brain MRI scan [see Castellanos et al., 2002 for details]. Ninety-four percent of the patients were diagnosed with ADHD combined type and the remaining 6\% were diagnosed with primary inattentive type. Whole blood was drawn from all probands and immediate family members. For the family-based analyses, 87 trios and 26 dyads were available. Forty-one of the original probands from the previously reported genetics study were included in the analysis [see Castellanos et al., 1998]. The current sample was 53\% male and the majority was Caucasian (75\% Caucasian, $12 \%$ African American, $10 \%$ Hispanic, $2 \%$ Asian and $1 \%$ other) with a mean age of $9.02 \pm 2.22$ years.

\section{Healthy Subjects}

Healthy subjects $(n=282$; average age $15.99 \pm 8.13$ years $)$ were recruited from the local community and nationally with no personal or family history of psychiatric or neurological disorders. All subjects were given age-appropriate versions of the WISC, and comprised 82\% Caucasian, 10\% African American, 3\% Hispanic, 3\% Asian, and 2\% mixed or other ethnicities. Either whole blood $(\mathrm{n}=149)$ or saliva samples $(\mathrm{n}=133)$ were collected for DNA isolation. There were no significant differences in allele frequencies or data quality between the different DNA sources. To assess genotype quality, 20 samples were randomly selected for repeat genotyping, and all genotypes were consistent.

\section{Nucleic Acid Purification and PCR}

DNA was available for 161 ADHD subjects and 282 normal controls. Genomic DNA was extracted from immortalized lymphoblastoid cells using the QIAamp DNA Extraction Kit (Qiagen, Inc., Valencia, CA) and saliva samples using PUREGENE ${ }^{\circledR}$ (www.gentra.com). The VNTR polymorphic site in exon 3 of the dopamine receptor D4 gene was amplified using primers D4-F-GCGACTACGTGGTCTACTCG and D4-R-AGGACCCTCATGGCCTTG. Reactions were performed in a 96 -well format in a total reaction volume of $25 \mu \mathrm{l}$ containing $2.6 \mu \mathrm{l}$ of $10 \eta \mathrm{g} / \mu \mathrm{l} \mathrm{DNA}, 1 \mu \mathrm{l}$ of each $10 \mu \mathrm{M}$ primer, $2.5 \mu \mathrm{l}$ of PCR buffer, $0.5 \mu \mathrm{l} \mathrm{MgCl}_{2}, 5 \mu \mathrm{l}$ of GC rich buffer, $2 \mu \mathrm{l}$ of 7 -deaza2 'Deoxy GTP dNTP mix, $0.2 \mu$ l of Fast Start Taq DNA polymerase and $2.6 \mu \mathrm{l}$ of $\mathrm{H}_{2} \mathrm{O}$ (Roche, https://shop.ibuybiochem.com/rasstoreus/rasstoreus.html). PCR was performed using 1 cycle of denaturation for $3 \mathrm{~min}$ at $95^{\circ} \mathrm{C}, 45$ cycles of annealing for $30 \mathrm{sec}$ at $95^{\circ} \mathrm{C}, 30 \mathrm{sec}$ at $62^{\circ} \mathrm{C}$, and $45 \mathrm{sec}$ at $72^{\circ} \mathrm{C}$, followed by 1 cycle of extension for $5 \mathrm{~min}$ at $72^{\circ} \mathrm{C}$. PCR products were run out on a $3 \%$ agarose gel at $100 \mathrm{~V}$ for $100 \mathrm{~min}$.

\section{Statistical Analysis}

COCAPHASE was used to compare allele frequencies in cases and controls [Dudbridge, 2003]. TDTPHASE was used for family-based TDT analyses. QTPHASE was used to examine genetic associations with quantitative phenotypes among the ADHD probands (http://www.hgmp.mrc.ac.uk/ $\sim$ fdudbrid/software/unphased/). One-tailed asymptotic $P$-values are reported for alleles that were previously reported to be associated in other studies.

\section{RESULTS}

The allele frequencies of the VNTR alleles in cases and controls are shown in Table I. ADHD patients had a higher frequency of the 7-repeat allele as compared to controls, $23 \%$ versus $17 \%$ respectively $(P=0.028)$. Conversely, the controls
TABLE I. Case Control Results

\begin{tabular}{lcccc}
\hline Allele & $\begin{array}{c}\text { Case } \\
\text { frequency }\end{array}$ & $\begin{array}{c}\text { Control } \\
\text { frequency }\end{array}$ & Odds ratio & $P$-value \\
\hline 2 & 0.10 & 0.09 & 1.00 & 0.632 \\
3 & 0.04 & 0.04 & 0.81 & 0.758 \\
4 & 0.62 & 0.68 & 0.82 & 0.040 \\
5 & 0.00 & 0.01 & 0.21 & 0.108 \\
6 & 0.01 & 0.00 & na & 0.048 \\
7 & 0.23 & 0.17 & 1.19 & 0.028 \\
8 & 0.00 & 0.00 & na & 0.163 \\
\hline
\end{tabular}

had a higher frequency of the 4-repeat allele $(62 \%$ in cases and $68 \%$ in controls, $P=0.04$ ), consistent with previous reports. This association was not confirmed in the TDT analyses, which assesses transmissions from parents to affected offspring (see Table II; global $P=0.79$ ).

The significant case control findings led to exploration of potential genetic associations with other phenotypic measures. There was evidence for significant association with three subscales of the WISC and the 7-repeat allele within the ADHD group. Specifically, probands with a 7-repeat allele had higher scores on the information $(P=0.01)$, and vocabulary $(P=0.01)$, and a trend for association with the similarities $(P=0.07)$, subscales of the WISC. In addition, we had follow-up information on a large proportion of the ADHD sample $(n=107)$ and had DNA on 69 of these 107. We categorized the follow-up sample as having "good" or "poor" outcome based on a median split of scores at follow-up on the Children's Global Assessment Scale (CGAS) [Shaffer et al., 1983; Shaw et al., 2006]. There was a higher frequency of the 7-repeat allele in the good outcome group as compared to the poor outcome group (28\% vs. $18 \%$, respectively), though this difference did not reach statistical significance, likely due to the small sample size $(P=0.11)$.

\section{DISCUSSION}

The current study confirms previous reports of an association between $\mathrm{ADHD}$ and the 7-repeat allele of the $D R D 4$ gene. This study represents an expanded sample of cases and controls collected at the NIMH, which originally reported no association [Castellanos et al., 1998], most likely due to a lack of power given the observation that the allele frequencies in that report were similar to those in the current expanded sample. Several case control studies from other research groups also found comparable allele frequencies of the 7-repeat polymorphism in their samples [LaHoste et al., 1996; Swanson et al., 1998; Holmes et al., 2000; Muglia et al., 2000; Tahir et al., 2000; Curran et al., 2001; Mill et al., 2001; Roman et al., 2001]. This study is notable as we report not only a trend for better clinical outcome among carriers of the DRD4 7-repeat allele, but also better cognitive abilities. These findings, along with previous reports in the literature, suggest that the 7-repeat allele may identify a subgroup with behavioral but not the

TABLE II. TDT Results

\begin{tabular}{lrcc}
\hline Alelle & Transmitted & Not transmitted & $P$-value \\
\hline 2 & 22 & 19 & 0.622 \\
3 & 6 & 9 & 0.429 \\
4 & 135 & 138 & 0.758 \\
5 & 1 & 1 & 1.000 \\
6 & 0 & 1 & 0.239 \\
7 & 45 & 41 & 0.628 \\
\hline
\end{tabular}


cognitive components of $\mathrm{ADHD}$ in carriers of this allele [Swanson et al., 2000].

There is considerable debate about the nature of the phenotype associated with the 7-repeat allele. Swanson et al. [2000] reported that 7-repeat carriers showed intact performance on tests of selective and executive attention, with normal reaction times and variability of response. By contrast, children with ADHD without the 7-repeat showed the neuropsychological profile that is thought to characterize the disorder of slow and variable reactions times. They proposed that the 7-repeat thus delineates a subtype of ADHD characterized by behavioral but not cognitive components of ADHD. This was essentially replicated by Manor et al. [2002], who showed that children with the 7-repeat had a more accurate response style on a variant of the continuous performance test. Our finding of better cognitive performance in those with the 7-repeat is also congruent with the concept of an intact cognitive profile, and is of particular interest given evidence that the 7-repeat may have arisen as a relatively new variant which is under positive selection [Ding et al., 2002].

However there are several conflicting findings. Firstly, Langley et al. [2004] found that ADHD children with the 7-repeat had a more inaccurate and impulsive response style. Also Mill et al. [2001] found that a lower IQ in ADHD subjects with the 7-repeat in two epidemiological cohorts. The discrepancies may partially relate to developmental factors. For example, the Langley report of a deleterious cognitive style in 7-repeat carriers studied a younger group (mean age of 9.2 years) than the subjects in Swanson's report of intact attention (this group had a mean 11.9 years). Comparisons between the studies is also complicated by the variety of experimental paradigms used, highlighting the need for a common neuropsychological battery for assessing the disorder.

Some limitations deserve mention. First, we observed a positive association only in the case control sample, not in the family sample utilizing the TDT test. This discrepancy is not completely accounted for by the slightly smaller sample size in the family-based analyses. The case-control finding also held when the allele frequency data was analyzed with Caucasians only ( $22 \%$ vs. $17 \%$ ) indicating that the positive case-control association was not simply due to population stratification. Second, all $P$-values are nominal and would not survive a multiple comparison correction. Therefore, the current findings need to be confirmed in independently collected samples.

In summary, we confirm the association of the DRD4 7-repeat allele with ADHD and delineate a possible phenotype. Additional studies utilizing such phenotypes may help reduce diagnostic heterogeneity within ADHD and help to better understand the underlying genetic influences [Castellanos and Tannock, 2002; Gottesman and Gould, 2003].

\section{ACKNOWLEDGMENTS}

We thank all of the families who participated in the ADHD study. We also express our gratitude to John Hardy and the staff in the Laboratory of Neurogenetics, National Institute of Aging, National Institutes of Health. Additionally, we thank Philip Asherson and coworkers at the Institute of Psychiatry, London, UK for their help with the DRD4 assay.

\section{REFERENCES}

Achenbach TM, Edelbrock CS. 1981. Behavioral problems and competencies reported by parents of normal and disturbed children aged four through sixteen. Monogr Soc Res Child Dev 46(1):1-82.

Achenbach TM, Howell CT, Quay HC, Conners CK. 1991. National survey of problems and competencies among four- to sixteen-year-olds: Parents' reports for normative and clinical samples. Monogr Soc Res Child Dev 56(3):1-131.
American Psychiatric Association. 1994. American Psychiatric Association diagnostic and statistical manual of mental disorders, Fourth Edition. Washington D.C.: American Psychiatric Association.

Arcos-Burgos M, Castellanos FX, Konecki D, Lopera F, Pineda D, Palacio JD, Rapoport JL, Berg K, Bailey-Wilson J, Muenke M. 2004. Pedigree disequilibrium test (PDT) replicates association and linkage between DRD4 and ADHD in multigenerational and extended pedigrees from a genetic isolate. Mol Psychiatry 9(3):252-259.

Bhaduri N, Das M, Sinha S, Chattopadhyay A, Gangopadhyay PK, Chaudhuri K, Singh M, Mukhopadhyay K. 2006. Association of dopamine D4 receptor (DRD4) polymorphisms with attention deficit hyperactivity disorder in Indian population. Am J Med Genet B Neuropsychiatr Genet Part B 141B:61-66.

Bobb AJ, Castellanos FX, Addington AM, Rapoport JL. 2005. Molecular genetic studies of ADHD: 1991 to 2004. Am J Med Genet B Neuropsychiatr Genet Part B 132B:109-125.

Casey BJ, Gordon CT, Mannheim GB, Rumsey JM. 1993. Dysfunctional attention in autistic savants. J Clin Exp Neuropsychol 15(6):933-946.

Castellanos FX, Tannock R. 2002. Neuroscience of attention-deficit/ hyperactivity disorder: The search for endophenotypes. Nat Rev Neurosci 3(8):617-628.

Castellanos FX, Lee PP, Sharp W, Jeffries NO, Greenstein DK, Clasen LS, Blumenthal JD, James RS, Ebens CL, Walter JM, et al. 2002. Developmental trajectories of brain volume abnormalities in children and adolescents with attention-deficit/hyperactivity disorder. Jama 288(14):1740-1748.

Castellanos FX, Lau E, Tayebi N, Lee P, Long RE, Giedd JN, Sharp W, Marsh WL, Walter JM, Hamburger SD, and others. 1998. Lack of an association between a dopamine-4 receptor polymorphism and attention-deficit/hyperactivity disorder: Genetic and brain morphometric analyses. Mol Psychiatry 3(5):431-434.

Comings DE, Gonzalez N, Wu S, Gade R, Muhleman D, Saucier G, Johnson P, Verde R, Rosenthal RJ, Lesieur HR, and others. 1999. Studies of the 48 bp repeat polymorphism of the DRD4 gene in impulsive, compulsive, addictive behaviors: Tourette syndrome, ADHD, pathological gambling, and substance abuse. Am J Med Genet 88(4):358-368.

Curran S, Mill J, Sham P, Rijsdijk F, Marusic K, Taylor E, Asherson P. 2001 QTL association analysis of the DRD4 exon 3 VNTR polymorphism in a population sample of children screened with a parent rating scale for ADHD symptoms. Am J Med Genet 105(4):387-393.

Ding YC, Chi HC, Grady DL, Morishima A, Kidd JR, Kidd KK, Flodman P, Spence MA, Schuck S, Swanson JM, and others. 2002. Evidence of positive selection acting at the human dopamine receptor D4 gene locus.[see comment]. Proc Nat Acad Sci USA 99(1):309-314.

Dudbridge F. 2003. Pedigree disequilibrium tests for multilocus haplotypes. Genet Epidemiol 25(2):115-121.

Eisenberg J, Zohar A, Mei-Tal G, Steinberg A, Tartakovsky E, Gritsenko I, Nemanov L, Ebstein RP. 2000. A haplotype relative risk study of the dopamine D4 receptor (DRD4) exon III repeat polymorphism and attention deficit hyperactivity disorder (ADHD). Am J Med Genet 96(3):258-261

Faraone SV, Biederman J. 1998. Neurobiology of attention-deficit hyperactivity disorder. Biol Psychiatry 44(10):951-958.

Faraone SV, Biederman J, Weiffenbach B, Keith T, Chu MP, Weaver A Spencer TJ, Wilens TE, Frazier J, Cleves M, and others. 1999. Dopamine D4 gene 7-repeat allele and attention deficit hyperactivity disorder. Am J Psychiatry 156(5):768-770.

Faraone SV, Perlis RH, Doyle AE, Smoller JW, Goralnick JJ, Holmgren MA, Sklar P. 2005. Molecular genetics of attention-deficit/hyperactivity disorder. Biol Psychiatry 57(11):1313-1323.

Fisher SE, Francks C, McCracken JT, McGough JJ, Marlow AJ, MacPhie IL, Newbury DF, Crawford LR, Palmer CG, Woodward JA, and others. 2002. A genomewide scan for loci involved in attention-deficit/hyperactivity disorder. Am J Hum Genet 70(5):1183-1196.

Gottesman II, Gould TD. 2003. The endophenotype concept in psychiatry: Etymology and strategic intentions. Am J Psychiatry 160(4):636645 .

Goyette CH, Conners CK, Ulrich RF. 1978. Normative data on revised Conners Parent and Teacher Rating Scales. J Abnorm Child Psychol 6(2):221-236.

Hawi Z, McCarron M, Kirley A, Daly G, Fitzgerald M, Gill M. 2000. No association of the dopamine DRD4 receptor (DRD4) gene polymorphism with attention deficit hyperactivity disorder (ADHD) in the Irish population. Am J Med Genet 96(3):268-272. 
Holmes J, Payton A, Barrett JH, Hever T, Fitzpatrick H, Trumper AL Harrington R, McGuffin P, Owen M, Ollier W, and others. 2000. A family-based and case-control association study of the dopamine D4 receptor gene and dopamine transporter gene in attention deficit hyperactivity disorder. Mol Psychiatry 5(5):523-530.

Holmes J, Payton A, Barrett J, Harrington R, McGuffin P, Owen M, Ollier W, Worthington J, Gill M, Kirley A, and others. 2002. Association of DRD4 in children with ADHD and comorbid conduct problems. Am J Med Genet 114(2):150-153.

LaHoste GJ, Swanson JM, Wigal SB, Glabe C, Wigal T, King N, Kennedy JL 1996. Dopamine D4 receptor gene polymorphism is associated with attention deficit hyperactivity disorder. Mol Psychiatry 1(2):121-124.

Langley K, Marshall L, van den Bree M, Thomas H, Owen M, O’Donovan M, Thapar A. 2004. Association of the dopamine D4 receptor gene 7-repeat allele with neuropsychological test performance of children with ADHD. Am J Psychiatry 161(1):133-138.

Manor I, Tyano S, Eisenberg J, Bachner-Melman R, Kotler M, Ebstein RP 2002. The short DRD4 repeats confer risk to attention deficit hyperactivity disorder in a family-based design and impair performance on a continuous performance test (TOVA). Mol Psychiatry 7(7):790-794.

Marino C, Giorda R, Vanzin L, Molteni M, Lorusso ML, Nobile M, Baschirotto C, Alda M, Battaglia M. 2003. No evidence for association and linkage disequilibrium between dyslexia and markers of four dopamine-related genes. Eur Child Adolesc Psychiatry 12(4):198202.

Mill J, Curran S, Kent L, Richards S, Gould A, Virdee V, Huckett L, Sharp J, Batten C, Fernando S, and others. 2001. Attention deficit hyperactivity disorder $(\mathrm{ADHD})$ and the dopamine $\mathrm{D} 4$ receptor gene: Evidence of association but no linkage in a UK sample. Mol Psychiatry 6(4):440444.

Muglia P, Jain U, Macciardi F, Kennedy JL, 2000. Adult attention deficit hyperactivity disorder and the dopamine D4 receptor gene. Am J Med Genet 96(3):273-277.

Ogdie MN, Macphie IL, Minassian SL, Yang M, Fisher SE, Francks C, Cantor RM, McCracken JT, McGough JJ, Nelson SF, and others. 2003. A genomewide scan for attention-deficit/hyperactivity disorder in an extended sample: Suggestive linkage on 17p11. Am J Hum Genet 72(5):1268-1279.

Purper-Ouakil D, Wohl M, Mouren MC, Verpillat P, Ades J, Gorwood P. 2005. Meta-analysis of family-based association studies between the dopamine transporter gene and attention deficit hyperactivity disorder. Psychiatr Genet 15(1):53-59.
Reich W. 2000. Diagnostic interview for children and adolescents (DICA). J Am Acad Child Adolesc Psychiatry 39(1):59-66.

Roman T, Schmitz M, Polanczyk G, Eizirik M, Rohde LA, Hutz MH. 2001 Attention-deficit hyperactivity disorder: A study of association with both the dopamine transporter gene and the dopamine D4 receptor gene. Am J Med Genet 105(5):471-478.

Shaffer D, Gould MS, Brasic J, Ambrosini P, Fisher P, Bird H, Aluwahlia S. 1983. A children's global assessment scale (CGAS). Arch Gen Psychiatry 40(11):1228-1231.

Shaw P, Lerch J, Greenstein D, Sharp W, Clasen L, Evans A, Giedd J Castellanos FX, Rapoport J. 2006. Longitudinal mapping of cortica thickness and clinical outcome in children and adolescents with attention-deficit/hyperactivity disorder. Arch Gen Psychiatry 63(5): 540-549

Smalley SL, Bailey JN, Palmer CG, Cantwell DP, McGough JJ, Del'Homme MA, Asarnow JR, Woodward JA, Ramsey C, Nelson SF. 1998. Evidence that the dopamine $\mathrm{D} 4$ receptor is a susceptibility gene in attention deficit hyperactivity disorder. Mol Psychiatry 3(5):427-430.

Sunohara GA, Roberts W, Malone M, Schachar RJ, Tannock R, Basile VS Wigal T, Wigal SB, Schuck S, Moriarty J, and others. 2000. Linkage of the dopamine D4 receptor gene and attention-deficit/hyperactivity disorder. J Am Acad Child Adolesc Psychiatry 39(12):1537-1542.

Swanson JM, Sunohara GA, Kennedy JL, Regino R, Fineberg E, Wigal T, Lerner M, Williams L, LaHoste GJ, Wigal S. 1998. Association of the dopamine receptor D4 (DRD4) gene with a refined phenotype of attention deficit hyperactivity disorder (ADHD): A family-based approach. Mol Psychiatry 3(1):38-41.

Swanson J, Oosterlaan J, Murias M, Schuck S, Flodman P, Spence MA Wasdell M, Ding Y, Chi HC, Smith M, et.al. 2000. Attention deficit/ hyperactivity disorder children with a 7-repeat allele of the dopamine receptor D4 gene have extreme behavior but normal performance on critical neuropsychological tests of attention. Proc Nat Acad Sci USA 97(9):4754-4759

Tahir E, Yazgan Y, Cirakoglu B, Ozbay F, Waldman I, Asherson PJ. 2000 Association and linkage of DRD4 and DRD5 with attention deficit hyperactivity disorder (ADHD) in a sample of Turkish children. Mol Psychiatry 5(4):396-404.

Thapar A, O'Donovan M, Owen MJ. 2005. The genetics of attention deficit hyperactivity disorder. Hum Mol Genet 14 Spec No. 2:R275-R282.

Werry JS, Sprague RL, Cohen MN. 1975. Conners' Teacher Rating Scale for use in drug studies with children-An empirical study. J Abnorm Child Psychol 3(3):217-229. 